\title{
Mycoplasma genitalium Protein of Adhesion Promotes the Early Proliferation of Human Urothelial Cells by Interacting with RPL35
}

\author{
Pei Dai, Xiangying Deng, Peng Liu, Lingling Li, Dan Luo, Yating Liao and Yanhua Zeng *(D)
}

check for updates

Citation: Dai, P.; Deng, X.; Liu, P.; Li, L.; Luo, D.; Liao, Y.; Zeng, Y. Mycoplasma genitalium Protein of Adhesion Promotes the Early Proliferation of Human Urothelial Cells by Interacting with RPL35. Pathogens 2021, 10, 1449. https://doi.org/ 10.3390/pathogens 10111449

Academic Editors: Subramanian Dhandayuthapani and Lawrence S. Young

Received: 18 September 2021 Accepted: 3 November 2021 Published: 8 November 2021

Publisher's Note: MDPI stays neutral with regard to jurisdictional claims in published maps and institutional affiliations.

Copyright: (c) 2021 by the authors. Licensee MDPI, Basel, Switzerland. This article is an open access article distributed under the terms and conditions of the Creative Commons Attribution (CC BY) license (https:// creativecommons.org/licenses/by/ $4.0 /)$.
Hunan Provincial Key Laboratory for Special Pathogens Prevention and Control, Hunan Province Cooperative Innovation Center for Molecular Target New Drug Study, Institute of Pathogenic Biology, Hengyang Medical College, University of South China, Hengyang 421001, China; 20202013110899@stu.usc.edu.cn (P.D.); xiangyingbszn@163.com (X.D.); pengliu@live.cn (P.L.); 20202013110964@stu.usc.edu.cn (L.L.); 20192013110765@stu.usc.edu.cn (D.L.); liaoyating@stu.usc.edu.cn (Y.L.)

* Correspondence: zengyihua21cn@usc.edu.cn

Abstract: Mycoplasma genitalium is a newly recognized pathogen associated with sexually transmitted diseases (STDs). MgPa, the adhesion protein of Mycoplasma genitalium, is the main adhesin and the key factor for M. genitalium interacting with host cells. Currently, the long-term survival mechanism of M. genitalium in the host is not clear. In this study, a T7 phage-displayed human urothelial cell (SVHUC-1) cDNA library was constructed, and the interaction of MgPa was screened from this library using the recombinant $\mathrm{MgPa}(\mathrm{rMgPa})$ as a target molecule. We verified that $60 \mathrm{~S}$ ribosomal protein $\mathrm{L} 35$ (RPL35) can interact with MgPa using far-Western blot and co-localization analysis. According to the results of tandem mass tag (TMT) labeling and proteome quantitative analysis, there were altogether 407 differentially expressed proteins between the pcDNA3.1(+)/MgPa-transfected cells and nontransfected cells, of which there were 6 downregulated proteins and 401 upregulated proteins. The results of qRT-PCR demonstrated that interaction between $\mathrm{rMgPa}$ and RPL35 could promote the expressions of EIF2, SRP68, SERBP1, RPL35A, EGF, and TGF- $\beta$. 3-(4,5)-Dimethylthiahiazo(-z-y1)3,5-di-phenytetrazoliumromide bromide (MTT) assays corroborated that the interaction between rMgPa and RPL35 could promote SV-HUC-1 cell proliferation. Therefore, our findings indicated that the interaction between $\mathrm{rMgPa}$ and RPL35 can enhance the expressions of transcription-initiation and translation-related proteins and thus promote cell proliferation. This study elucidates a new biological function of $\mathrm{MgPa}$ and can explain this new mechanism of M. genitalium in the host.

Keywords: Mycoplasma genitalium; MgPa; T7 phage-displayed cDNA library; interacting proteins; RPL35

\section{Introduction}

Mycoplasma genitalium is an emerging pathogen causing genitourinary tract infections in both men and women. The bacterium is reportedly linked to male urethritis and adverse reproductive sequelae in women, including cervicitis, endometritis, pelvic inflammatory diseases, and nongonococcal urethritis [1]. Researchers have proven that M. genitalium is closely associated with human immunodeficiency virus (HIV) infection and can promote the replication of HIV after invading host cells [2-4]. M. genitalium can also combine with motile male sperm and, thus, lead to diffuse infection, which causes reproductive diseases and infertility [5].

The initial adhesion of M. genitalium to host cells is considered to be essential for the colonization of $M$. genitalium, leading subsequently to human urethritis [6]. The M. genitalium protein of adhesion, $\mathrm{MgPa}$, is a key adhesion component located on the surface of the terminal organelle of M. genitalium and plays vital roles in the pathogen's adhesion to and invasion of host cells [7]. The adhesion of M. genitalium to host cells also requires the participation of some auxiliary proteins, such as P32, P114, P110, and MG218. 
When these proteins are absent, the MgPa cannot be located at the terminal organelle, thus affecting the adhesion and infectivity of the M. genitalium to host cells [8].

M. genitalium's infection or invasion of host cells is carried out through the process of interaction between M. genitalium and host cells. M. genitalium adhesion proteins are multifunctional proteins, in addition to their critical role in cell adhesion, they are important for locomotion and cell invasion [9-20]. Therefore, adhesion proteins are virulence factors that are essential for colonization, communication, and persistent infection of M. genitalium. McGowin et al.'s findings suggested that M. genitalium invades host cells rapidly, utilizing intracellular survival niches to evade the effective cellular immune responses of the host [11]. However, the mechanism of primary infection and persistence of M. genitalium in host tissues is unclear.

Ribosome, the major organelles involved in protein biosynthesis, participate mainly in the synthetic process involving the translation of mRNA into protein [12]. Mature ribosomes consist of a large subunit and a small subunit, and each subunit consists of one or more ribosomal (rRNA) molecules and ribosomal proteins (RPs). RP is the main component of ribosomes and plays a significant role in the biosynthesis of intracellular proteins [13]. Previous studies confirmed that RPs not only participate in the biosynthesis of ribosomes but also play independent roles in protein biosynthesis processes, such as cell proliferation, apoptosis and differentiation, and the translation of mitochondrial proteins [14]. The 60S ribosomal protein L35 (RPL35) is an important component of a ribosomal subunit and plays a central role in protein translation and endoplasmic reticulum docking [15].

In our previous study, the soluble recombinant $\mathrm{MgPa}(\mathrm{rMgPa})$ containing the dominant epitope (1075-1364 aa) with strong immunogenicity and low homology with M. pneumoniae adhesion protein $\mathrm{P} 1$ was expressed and purified [16]. In the present study, a T7 phagedisplayed human urothelial cell (SV-HUC-1) cDNA library was constructed to screen the interacting protein of $\mathrm{rMgPa}$. The interaction between $\mathrm{MgPa}$ and the interacting protein was proven in vitro and intracellularly using far-Western blotting and co-location analysis. The effects of the interaction between $\mathrm{rMgPa}$ and the interacting protein on the function of SV-HUC-1 cells was analyzed through TMT protein quantitative analysis. Our study is aimed at further understanding the interaction between $M$. genitalium and the host to provide an experimental basis for the possible survival strategy of M. genitalium.

\section{Results}

\subsection{The T7 Phage-Displayed cDNA Library of SV-HUC-1 Cells Was Successfully Constructed}

The T7 phage-displayed cDNA library of SV-HUC-1 cells was constructed in order to screen the rMgPa-interacting proteins from the human urethral epithelium. Total RNA was extracted from SV-HUC-1 cells. The results showed that the ds-cDNA was synthesized by reverse transcription and analyzed by agarose electrophoresis (Figure 1A). Then, the bands of $28 \mathrm{~S}$ and $18 \mathrm{~S}$ RNA were clear (Figure 1B), which indicated that the extracted total RNA has good quality. The results showed that mRNA with high purity was isolated, and the ds-cDNA fragment could be used for further experiments. Fifteen plaques selected randomly were successfully amplified by PCR (Figure 1C), which demonstrated that the recombination rate of the library reached $93.75 \%(15 / 16)$. The exogenous DNA fragments inserted into phages were all within the range of 250-1000 bp, which demonstrated that the library has good diversity. Results from BLAST analysis revealed that these inserted sequences were all derived from the human genome DNA, which indicated that the cDNA library of SV-HUC-1 cells was constructed successfully. The SV-HUC-1 T7 phage-display cDNA library constructed by our research group was amplified in the host strain BLT5403 (Supplementary Materials Figure S1). The library was used subsequently for biopanning in this study. 


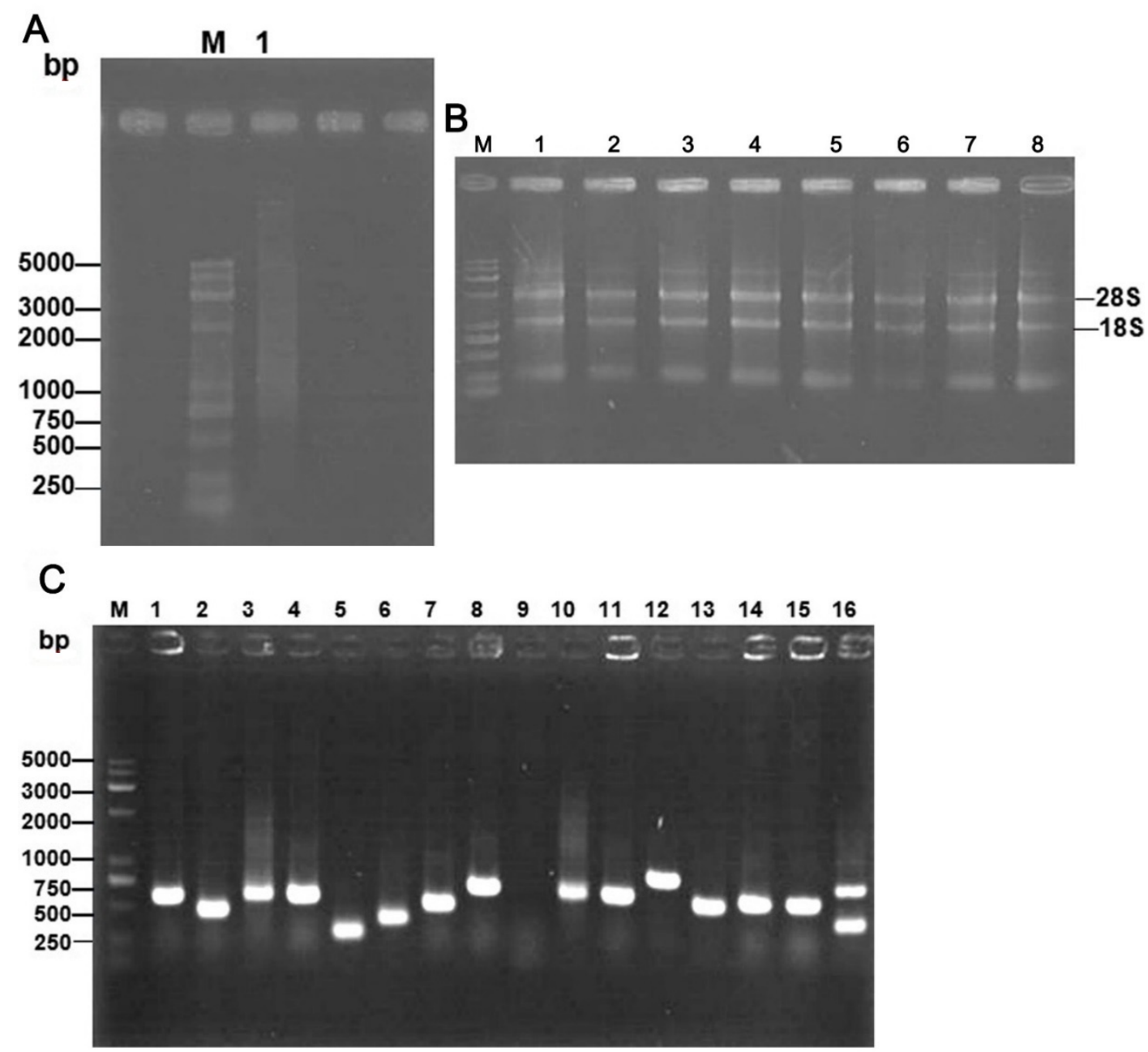

Figure 1. Construction of T7 phage-displayed cDNA library of SV-HUC-1 cells. (A) Electropherogram of ds cDNA extracted from SV-HUC-1 cells. (B) Agarose gel electropherogram of total RNA from SV-HUC-1 cells. M: DNA marker DL5000. 1: ds cDNA. (C) PCR products of random clones of the cDNA library were detected by agarose gel electrophoresis. M: DNA marker 1-26. Numbers of different random clones.

\section{2. $r M g P a-S p e c i f i c ~ T 7$ Phages Were Enriched Successfully}

First, we conducted four rounds of affinity biopanning, the phage yield ranged from $0.67 \times 10^{-4}$ to $1.7 \times 10^{-3}$, the results showed that the phage with specific binding to $\mathrm{rMgPa}$ was significantly enriched (Table 1). In order to analyze the foreign DNA sequences inserted into T7 bacteriophages, the PCR amplification products from positive plaques were sequenced and then analyzed by BLAST alignment. Agarose gel electrophoresis analysis of PCR products of the displayed phages are shown in Supplementary Materials Figure S2. The results showed that there were 7 different sequences (named representative phages P1-P7) for all 32 phages that displayed exogenous sequences. The occurrence frequency of P1 was the highest (62.5\%), and the $455 \mathrm{bp}$ base pair inserted $\mathrm{P} 1$ was $99 \%$ homologous with the 21st-475th DNA sequence of the RPL35 gene. The protein ID, coded protein, matched sequence range, homology, and repeated times of representative phages are listed in Table 2. These results indicated that the seven proteins might be rMgPa-specific binding proteins, and RPL35 might be a dominant rMgPa-interacting protein challenged from the T7 phage-displayed cDNA library of SV-HUC-1 cells. The result of the agarose gel electrophoresis analysis of PCR products for partial phages is shown in Supplementary Materials Figure S2. 
Table 1. The input, output, and ratio for biopanning of library.

\begin{tabular}{ccccc}
\hline Rounds & First & Second & Third & Fourth \\
\hline Input (pfu) & $3 \times 10^{8}$ & $3 \times 10^{8}$ & $3 \times 10^{8}$ & $3 \times 10^{8}$ \\
Output (pfu) & $2 \times 10^{4}$ & $4.2 \times 10^{4}$ & $1.9 \times 10^{5}$ & $5 \times 10^{5}$ \\
Ratio & $0.67 \times 10^{-4}$ & $1.4 \times 10^{-4}$ & $6.3 \times 10^{-4}$ & $1.7 \times 10^{-3}$ \\
\hline
\end{tabular}

Table 2. BLAST analysis for exogenous DNA sequences of positive phages.

\begin{tabular}{cccccc}
\hline Number & Coded Protein & mRNA ID & Matched Sequence Range & Similarity & Repeated Times \\
\hline P1 & RPL35 & NM_007209.4 & $102-196 \mathrm{bp}$ & $100 \%$ & 20 \\
P2 & Mitochondrial & NC_012920.1 & $1312-1600 \mathrm{bp}$ & $99 \%$ & 3 \\
P3 & complete genome & NM_020532.5 & $391-490 \mathrm{bp}$ & $100 \%$ & $100 \%$ \\
P4 & RTN4 & NM_004373.4 & $15-344 \mathrm{bp}$ & $99 \%$ & 2 \\
P5 & RPL21 & NM_000982.4 & $50-494 \mathrm{bp}$ & $99 \%$ & 2 \\
P6 & RPS23 & NM_001025.5 & $32-453 \mathrm{bp}$ & $99 \%$ & 1 \\
P7 & RPS26 & NM_001029.5 & $250-597 \mathrm{bp}$ & & 32 \\
\hline Total & & & & \\
\hline
\end{tabular}

Note: Homological analysis results for the inserted exogenous DNA sequences of 32 phages; the 7 representative phages were numbered as P1 to P7 $(n=32)$.

\subsection{The Representative Phages Could Combine Specially with $r \mathrm{MgPa}$}

Indirect ELISA was performed to verify whether the representative phages could combine specific with rMgPa. Results showed that the optical density (OD) values of the seven representative phages were much higher than that of the bovine serum albumin (BSA) control group $(p<0.05)$, which demonstrated that these representative phages could bind specially to $\mathrm{rMgPa}$ (Figure 2A). To further verify whether the representative phages were $\mathrm{rMgPa}$ specific, the dot immunobinding assay was used to detect the interaction between $\mathrm{rMgPa}$ and these representative phages. As shown in Figure 2B, representative phages and positive control groups showed clear spots, while no spots appeared for the control group. These results confirmed those of the ELISA. In addition, these results indicate that the seven representative phages could specifically combine with $\mathrm{rMgPa}$.

\section{4. $r M g P a$ Interacts with RPL35}

The eukaryotic expression vector of rMgPa was constructed, and the expression of rMgPa into cells was detected by Western blot (Supplementary Materials Figures S3 and S4). Far-Western blotting was performed to confirm whether RPL35 could interact with $\mathrm{rMgPa}$. As shown in Figure 3, there were bands of about $37 \mathrm{kDa}$ in every group, except for the negative and blank control, which suggested that RPL35 could interact with rMgPa in vitro.

\section{5. $r M g P a$ and RPL35 Could Interact in SV-HUC-1 Cells}

Co-localization assays were performed to determine whether RPL35 could interact with rMgPa in SV-HUC-1 cells. Firstly, we observed, after indirect immunofluorescence, that the pcDNA3.1(+)/rMgPa vector was transfected successfully into SV-HUC-1 cells (Figure 4A). The results of a double immunofluorescence staining in SV-HUC-1 cells showed that the immunoreactivities between RPL35 and rMgPa were distributed mainly in the cytoplasm and nuclear region (Figure 4B). These results indicate that rMgPa could interact with RPL35 intracellularly. 


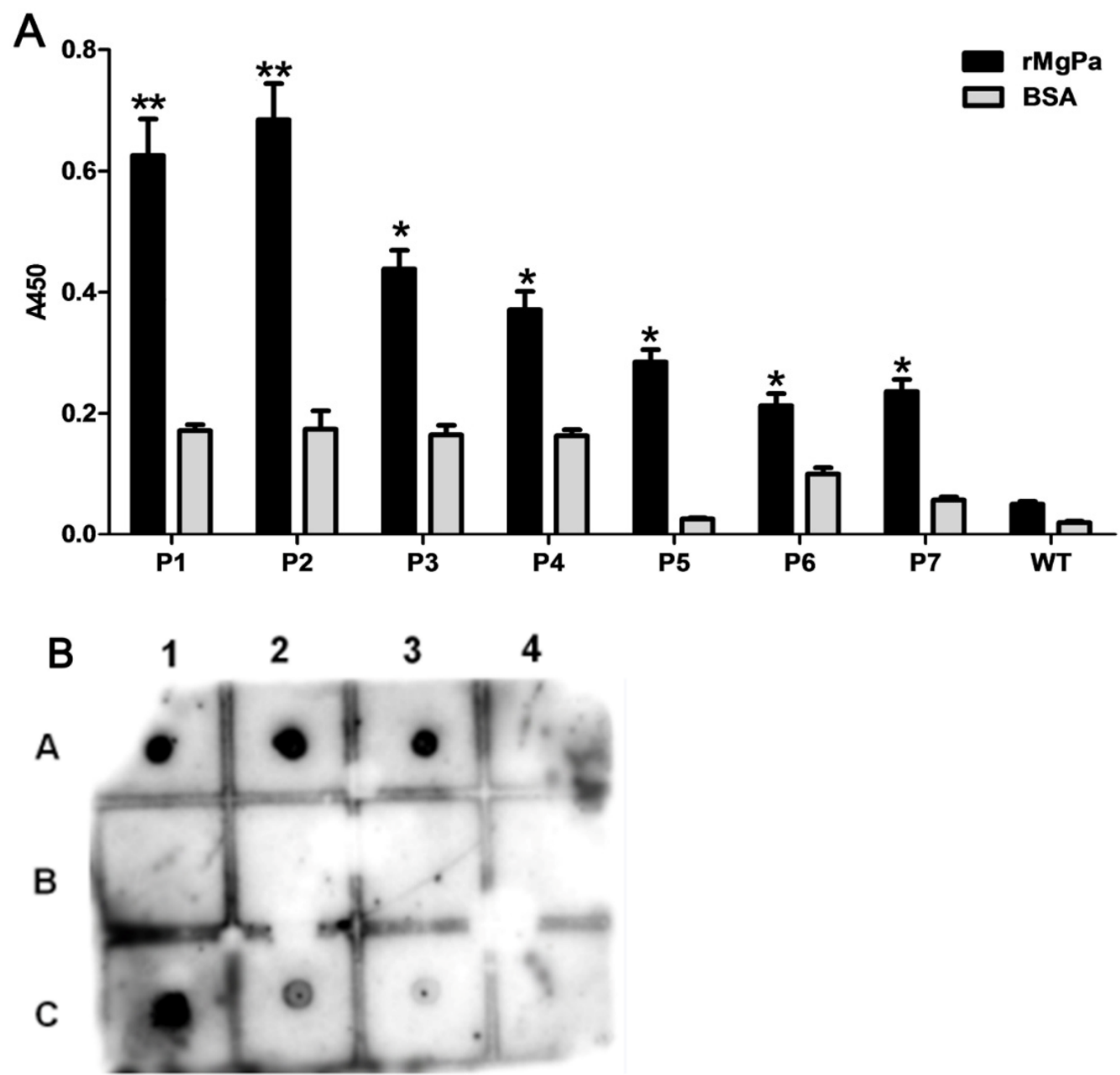

Figure 2. rMgPa-specific T7 phages were enriched successfully. (A) The specific combinations between representative phages and rMgPa were detected by ELISA. Note: P1-P7: number of representative phages. WT: wildtype phage. BSA was used as blank control. The note ${ }^{* *}$ indicates $p<0.01$ compared with the BSA group, ${ }^{*}$ indicates $p<0.05$ compared with the BSA group. (B) The specific combinations between representative phages and $\mathrm{rMgPa}$ were detected by dot immunobinding. Note: A1-A4: representative phages P1-P4; B1: WT control; B2: BSA control; B3-B4: blank control; C1: rMgPa positive control; C2-C4: representative phages P5-P7.

\section{1}

\section{2}

\section{$37 \mathrm{KDa}-$}

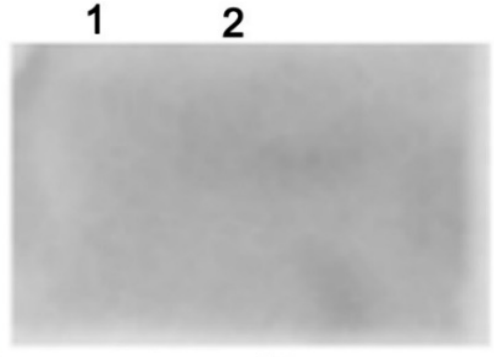

A
B

Figure 3. The interaction between rMgPa and RPL35 was detected by far-Western blot. rMgPa was incubated with total cell proteins and then with anti-RPL35 antibody and HRP-conjugated goat anti-rabbit IgG antibody, and there was a distinct band at $37 \mathrm{kDa}$, whereas no band was observed for the control group (in which rMgPa was incubated directly with anti-RPL35 antibody). Note for (A) the membrane was incubated with total cell proteins and for (B) it was not. Lane1: no rMgPa (blank control); 2: $\mathrm{rMgPa}$. 

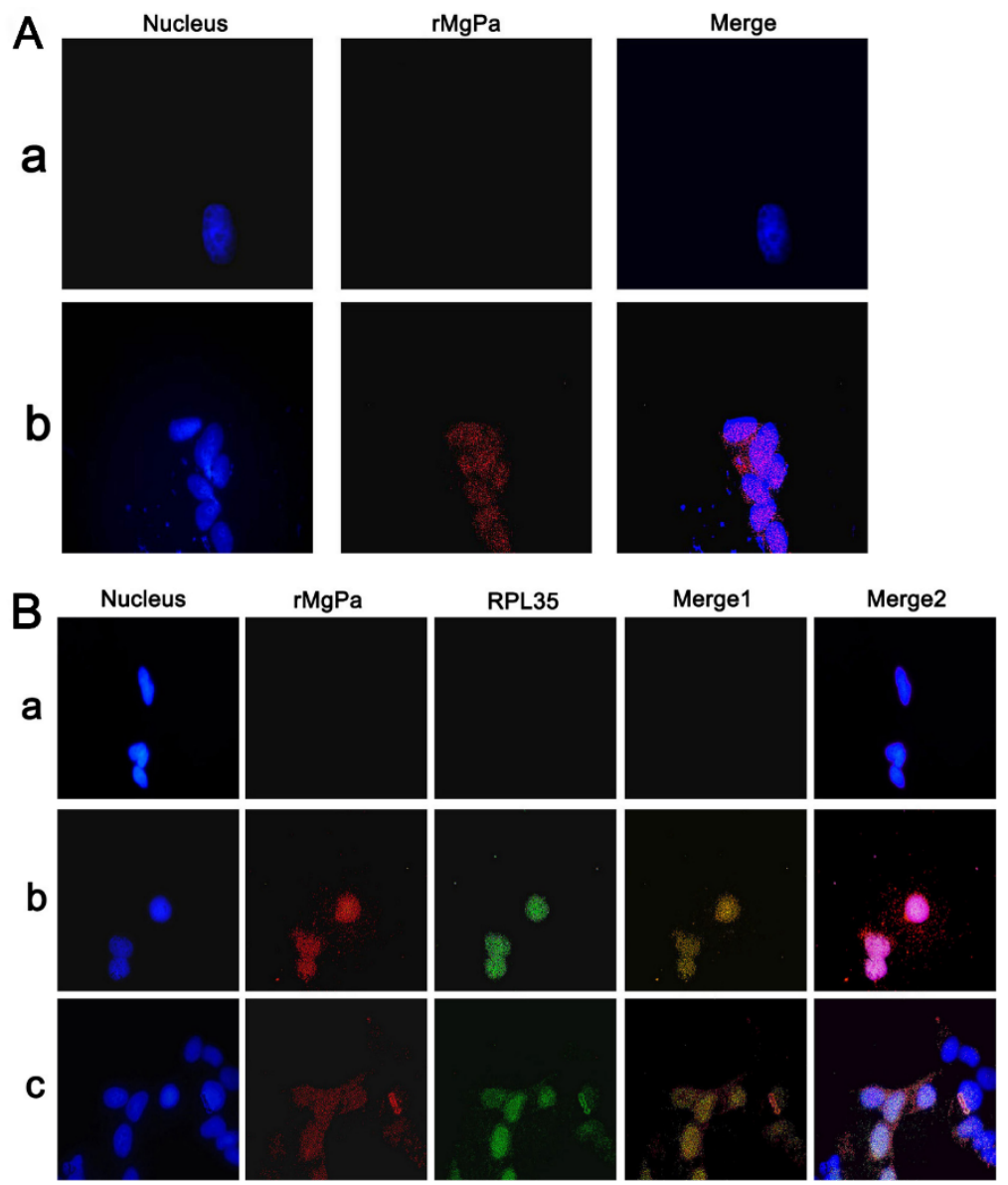

Figure 4. rMgPa and RPL35 could interact in SV-HUC-1 cells. (A) The pcDNA3.1(+)/MgPatransfected SV-HUC-1 cells were detected using indirect immunofluorescence $(100 \times)$. SV-HUC-1 cells were fixed, blocked, and incubated with anti-MgPa antibody followed by incubation with Cy3conjugated AffiniPure goat anti-rabbit $\operatorname{IgG}(\mathrm{H}+\mathrm{G})$, then the cells were incubated with DAPI staining solution (DAPI). Note: a: control; b: pcDNA3.1(+)/MgPa groups. Representative images are shown. (B) Co-location of RPL35 and rMgPa in SV-HUC-1 cells $(100 \times)$. Transfection of different concentrations of pcDNA3.1(+)/MgPa. The cells were prepared and incubated with the primary antibody mixture containing rabbit anti-rMgPa antibody and mouse anti-RPL35 antibody, then incubated with the second antibody mixture containing FITC-conjugated AffiniPure goat anti-mouse $\operatorname{IgG}(\mathrm{H}+\mathrm{G})$ and TRITC-conjugated AffiniPure goat anti-rabbit $\operatorname{IgG}(\mathrm{H}+\mathrm{L})$, the cells were then incubated with DAPI. Note: a: control; b: $6 \mu \mathrm{g}$ pcDNA3.1(+)/MgPa; c: $4 \mu \mathrm{g}$ pcDNA3.1(+)/MgPa; nucleus (blue), rMgPa (red), RPL35 (green). Merge 1 was composed of red (rMgPa) and green (RPL35), Merge 2 was composed of red (rMgPa), green (RPL35), and blue (nucleus). Representative images are shown.

\subsection{Differential Proteins Were Identified Successfully by TMT Analysis}

To further explore the effect of the rMgPa and RPL35 interaction on cell function, the TMT protein quantitative assay was implemented to screen the differential proteins before and after pcDNA3.1(+)/MgPa was transfected into SV-HUC-1 cells. A total of 3843 proteins were identified, of which 407 proteins were expressed differentially. Compared with the empty-plasmid-transfected group, 6 proteins were downregulated, and 401 proteins were upregulated for the pcDNA3.1(+)/MgPa-transfected group. As far as the biological process was concerned, these proteins were involved mainly in the co-translation of the signal recognition particle subunit (SRP), translation initiation, and transcription of mRNA by GO enrichment analysis (Figure 5A). Regarding the cellular composition, these proteins were mainly related to ribosomes. In terms of molecular function, these differential proteins were mainly related to the binding and structural composition of RNA. The enrichment 
of differential protein in the KEGG pathway showed that it was mainly concentrated in the ribosomal signaling pathway and citrate cycle. The clustering of differentially expressed proteins in the control and the transfection group is shown in Figure 5B, where red represents upregulated proteins, green represents downregulated proteins. The differentially expressed proteins were mainly related to cell adhesion, intercellular junction, and defensive and immune-related proteins, as shown in Figure 5C.

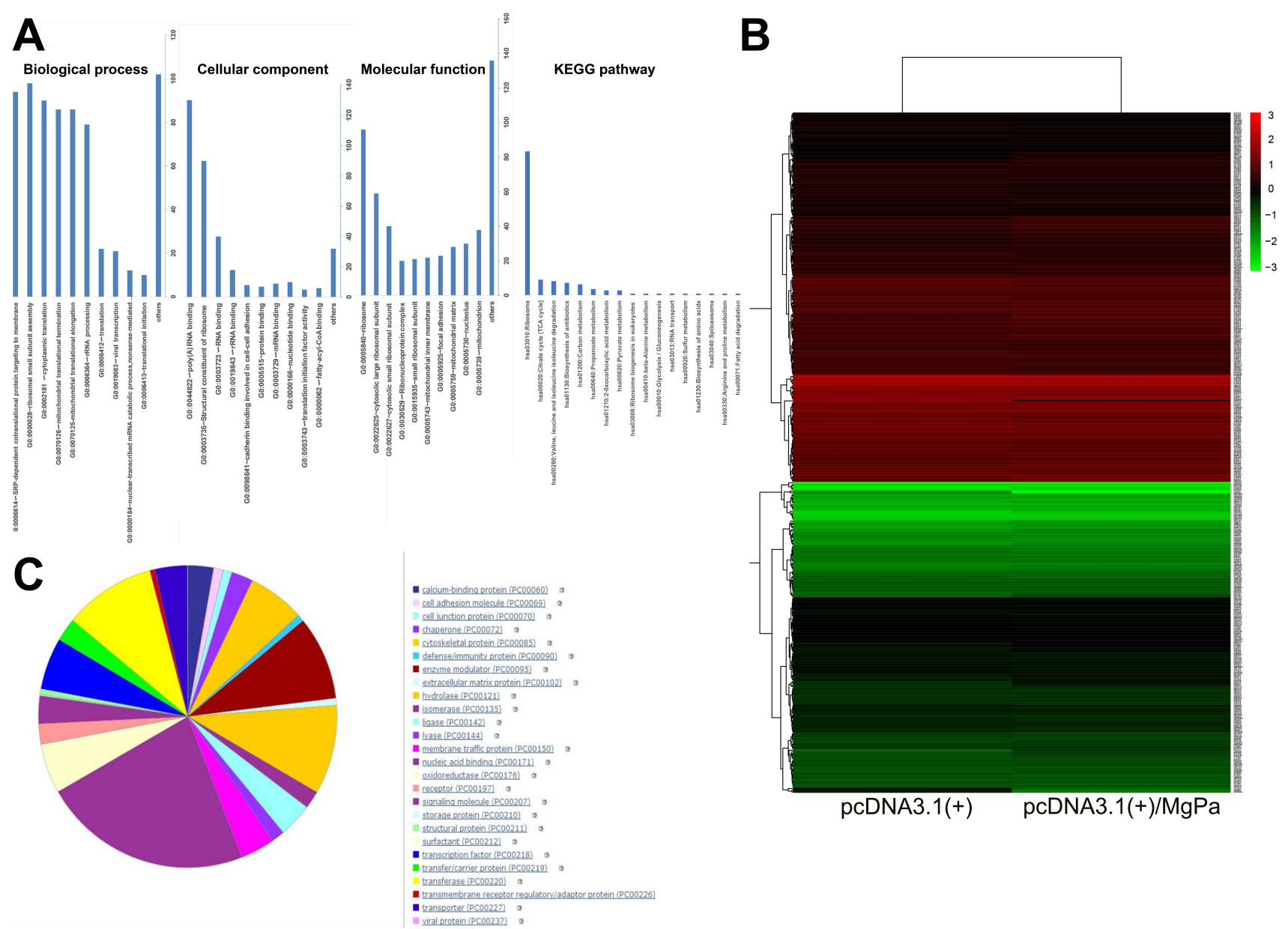

Figure 5. Differential protein analysis. The transfection group and the empty-plasmid group were established. Gene ontology of differential proteins. (A) GO enrichment analysis. (B) Thermal analysis of differential proteins. (C) PANTHER protein class categories of total DEGs.

\subsection{The mRNA Expressions of Representative Factors Were Increased}

Representative factors related to co-translation, translation initiation, ribosomal assembly, and RNA transcription, such as EIF2, SRP68, SERBP1, RPL35A, EGF, and TGF- $\beta$ were selected for the analysis of their gene expression levels using RT-qPCR. As shown in Figure 6, the expression of all these genes increased to some extent after pcDNA3.1(+)/MgPa was transfected into SV-HUC-1 cells, and TGF- $\beta$, RPL35A, and SRP68 expressions were increased significantly. These results were consistent with those from the TMT analysis. All these findings showed that the interaction between $\mathrm{rMgPa}$ and RPL35 could regulate the transcription and translation of these proteins. 


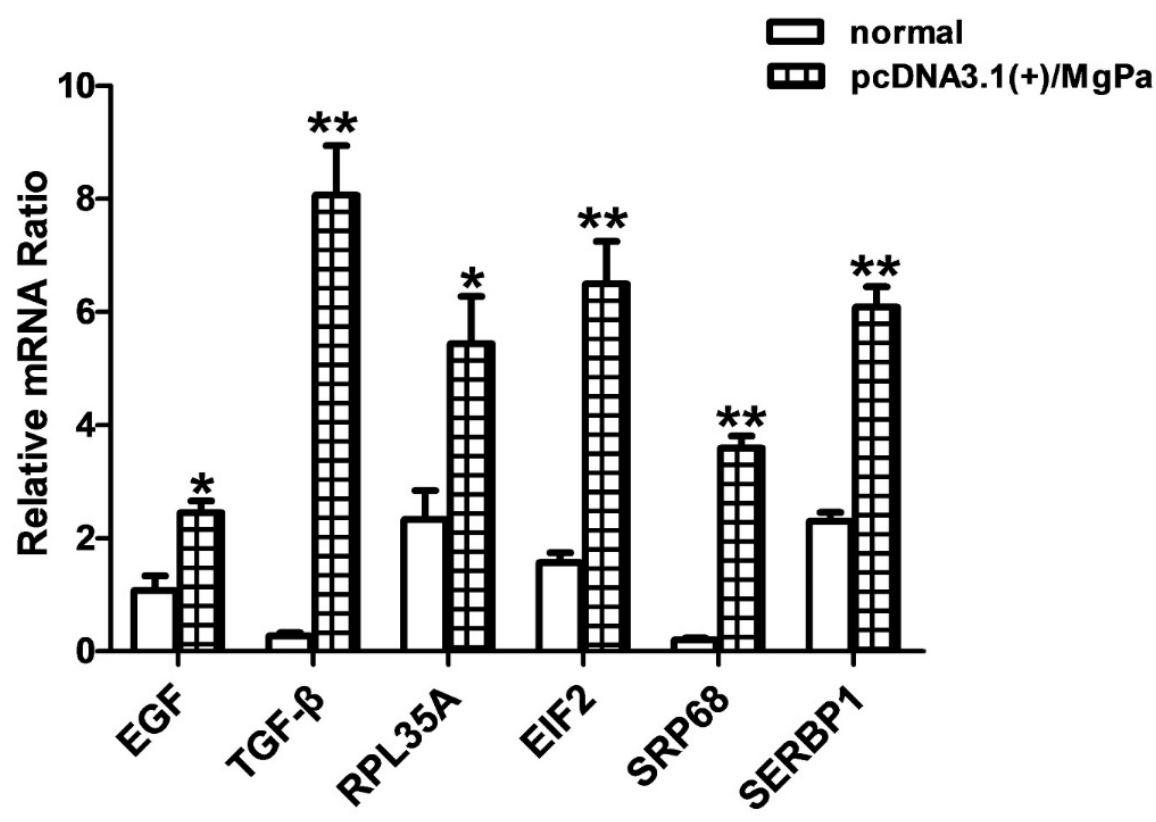

Figure 6. The mRNA expressions of representational factors were verified by RT-qPCR $(n=3)$. The mRNA expressions of representative differential proteins in the empty-plasmid group and the transfection group were detected by RT-qPCR. As shown in the figure, the expression of mRNA the transfection group was significantly higher than in the normal group. Note: * represents $p<0.05$ and ** represents $p<0.01$.

\subsection{The Interaction between rMgPa and RPL35 Can Promote Cell Proliferation}

MTT assays were used to further explore the effects of the interaction between rMgPa and RPL35 on SV-HUC-1 cells proliferation. As shown in Figure 7, the cell proliferation levels were increased at 24,36, and $48 \mathrm{~h}$ after pcDNA3.1(+)/MgPa was transfected into cells, but this proliferation was inhibited at $72 \mathrm{~h}$ after the transfection. Hence, the interaction between rMgPa and RPL35 could promote cell proliferation at an early stage of M. genitalium infection.

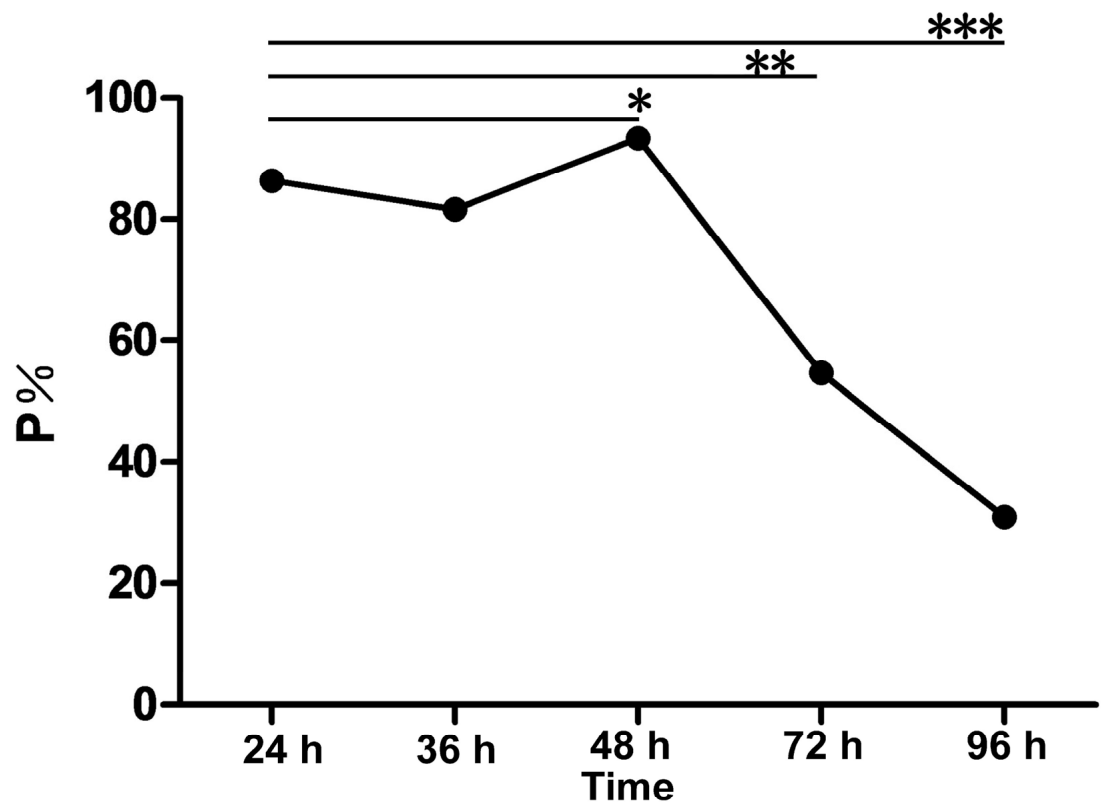

Figure 7. Proliferation of SV-HUC-1cells transfected with pcDNA3.1(+)/MgPa was detected by MTT $(n=3)$. The effect at the different time points of transfected with pcDNA3.1(+)/MgPa on cell proliferation is shown. Cell culture medium was planted in a 96-well plate overnight. After stimulating 
the cells, MTT solution was added to each well; later, formazan solution was added. Finally, absorbance was determined at $495 \mathrm{~nm}$ wavelength. Note: cell proliferation rate (P\%), setting different groups (experimental group, EG; control group, $C G$ ) and culture medium as the zeroing group (ZG). $\mathrm{P} \%=\times(\mathrm{ODEG}-\mathrm{ZG}) / \times(\mathrm{OD} C G-\mathrm{ZG}) \times 100 \%$. Note: ${ }^{*}$ represents $p<0.05,{ }^{* *}$ represents $p<0.01$ and ${ }^{* * *}$ represents $p<0.001$.

\section{Discussion}

Mycoplasma genitalium was first isolated from the urethral secretions of a patient with nongonococcal urethritis and can cause urogenital infection. The bacterium has been linked to the death of patients suffering from HIV infection [17]. The adhesion of M. genitalium to host cells is the key to its colonization and subsequent invasion. $\mathrm{MgPa}$ is one of the most important adhesion proteins located mainly in the terminal organelle of M. genitalium. Mycoplasma genitalium's process of infection or invasion into host cells is mediated by its adhesion proteins, which make it capable of causing damage to and the death of host cells. The essence of this process is the interaction between M. genitalium and the host cells. Ueno et al. demonstrated that $M$. genitalium can invade cervical carcinoma epithelial cells and non-cancerous endometrial cells (EM42) [18]. Mycoplasma genitalium penetrates Vero cells through its terminal organelle and colonizes its membrane-binding follicles [19]. Baseman et al. verified that $M$. genitalium survives up to 7 days in mammalian cells [20]. Mycoplasma genitalium can also replicate its DNA in host cells and increase its population [21].

However, few studies on the interaction between M. genitalium and host cells have been carried out. Based on the persistent infection caused by M. genitalium in vivo, there may be a mechanism that is beneficial to the long-term survival of M. genitalium in the host cells. Therefore, it is necessary to clarify how M. genitalium interacts with host cells and its survival mechanism after invading into the host cells. Researchers can insert a target DNA fragment into a phage genome to form a new fusion gene and display it on the surface of a phage using a phage-display technique [22]. Proteins or molecules of interest can be screened from phage-displayed libraries via several rounds of biopanning. At the same time, the non-specific phages can be removed by negative panning. Finally, the phages that bind to the specific target molecule can be obtained. Compared with other bacteriophages, the T7 phage particles exhibit high stability under various extreme conditions, including high temperature and low $\mathrm{PH}$, thereby achieving efficient high-throughput affinity elution [23]. T7 phage-display system is mainly used in antigen epitope screening, vaccine development, protein interaction, and cancer diagnosis and treatment. For example, T7 phage display has been used to screen K-Ras(G12D)-selective inhibitor, which can inhibit A427 cancer cell proliferation [24]. Talwar et al. identified 10 highly significant Mycobacterium tuberculosis (TB) clones of smear-positive pulmonary tuberculosis patients by using the T7 phage-display technique. This can be used as an immunogenic antigen of therapeutic or prophylactic vaccines and as a target for tuberculosis treatment [25].

Our previous study confirmed that cyclophilin A (СуpA), the key player for etiological agent's infection, is the receptor protein of $\mathrm{MgPa}$, which can partially inhibit $M$. genitalium from adhesion and even invasion into human urethral epithelial cells $[16,26]$. Our previous study also validated that MgPa can stimulate the secretion of CyPA in SV-HUC-1 cells and, thus, promote the expression of inflammatory cytokines through the CyPA-CD147-ERKNF- $\mathrm{kB}$ signal pathway [27]. However, the specific MgPa protein may have many different interacting proteins. It is not hard to understand, plasminogen has more than one dozen plasminogen-interacting proteins [28]. It is possible to screen out different interacting proteins using different methods. Although the phage-display technique we used did not show that CyPA could interact with $\mathrm{MgPa}$, the reason may be that we selected a relatively limited number of plaques $(n=50)$, which may be made up by expanding the sample size. However, the RPL35 we screened was present in the mass spectrometry sequencing of Deng et al. Differences in methods lead to some differences in research results, but this is 
not controversial. The interaction proteins screened by different methods will only enrich our research on the molecular function of $\mathrm{MgPa}$.

In this study, the T7 phage-displayed cDNA Library of SV-HUC-1 cells was successfully constructed and challenged using the purified $\mathrm{rMgPa}$ as a target molecule to screen the interacting protein of $\mathrm{rMgPa}$ from the whole genome of SV-HUC-1 cells. According to the results of DNA sequencing and homology analysis, seven representative bacteriophages that could specifically bind to rMgPa were screened and verified by phage ELISA and dot immunoassay. Results from far-Western blot and co-localization assays further confirmed that 60S ribosomal protein L35 (RPL35) from SV-HUC-1 cells could interact with rMgPa. Therefore, this study confirmed that RPL35 may be another interacting protein of $\mathrm{MgPa}$ besides CypA. This indicated that different $\mathrm{MgPa}$ interacting proteins may play different physiological roles during different processes of $M$. genitalium infection.

To investigate the effect of the interaction between rMgPa and RPL35 on cell function, TMT protein quantitative analysis was performed to screen differentially expressed proteins before and after pcDNA3.1(+)/MgPa was transfected into SV-HUC-1 cells. TMT is an in vitro chemical labeling reagent that can specifically label peptides produced by the enzymatic hydrolysis of proteins [29]. Because of its high efficiency and ability to label the ends of all peptides, TMT can provide a basis for the quantitative analysis of proteins. Therefore, it was used widely in the study of the pathogenesis of some diseases and biomarkers [30]. Crozier et al. identified hundreds of proteins related to the cell cycle regulation of Trypanosoma brucei using TMT analysis [31].

Based on the TMT technique, important differential proteins were screened after pcDNA3.1(+)/MgPa was transfected into cells in this study. The results showed that 401 proteins were upregulated, while 6 proteins were downregulated, with most of the upregulated proteins playing roles in the transcriptional initiation and translation of proteins, such as the SRP-dependent co-translation protein targeting of members (GO: 0006614), ribosome (GO:0005840), RNA binding (GO:0044822), and the main KEGG pathway including ribosome (hsa03010), which indicated that the interaction between $\mathrm{MgPa}$ and RPL35 could promote the transcription and translation of cellular proteins. In terms of cell composition, these upregulated proteins were mainly ribosome-related proteins, which suggested that the interaction between rMgPa and RPL35 could upregulate the expression of ribosome-related proteins. Representative factors associated with co-translation, translation initiation, ribosomal assembly, and mRNA transcription, including epidermal growth factor (EGF), eukaryotic translation initiation factor 2 (EIF2), signal recognition particle subunit 68 (SRP68), plasminogen activator inhibitor 1 RNA-binding protein (SERBP1), ribosomal protein L35A (RPL35A), and transforming growth factor beta-1-induced transcript protein (TGF- $\beta$ ) were selected for additional analysis. The mRNA expressions of these proteins were increased significantly after pcDNA3.1(+)/MgPa was transfected into cells, which suggested that the interaction between rMgPa and RPL35 could promote the transcription and translation of these proteins. These results were consistent with those of the TMT analysis.

$\mathrm{RP}$, a major component of the ribosome, plays an important role in intracellular protein biosynthesis [32]. The ribosome-independent functions of RP include the regulation of cell proliferation, differentiation, and apoptosis [33]. RP is also closely related to tumorigenesis [34]. Interestingly, a growing number of studies have shown that RP has extracorporeal functions, based on which several criteria for determining RP-ribosomal extracellular functions have been proposed. Firstly, RP can interact with other non-ribosomal components inside the cell. Secondly, the interaction between RP and non-ribosomal components can lead to some physiological effects for cells. Thirdly, this physiological effect does not depend on the function of the ribosome itself but is independent of the ribosome $[35,36]$. In the process of ribosome synthesis, the dynamic balance between rRNA and RP needs to be achieved. Therefore, at a certain stage, some components of RP act as transcription inhibitors to regulate this balance. For example, RPL4 binds to a specific site of the promoter of the RPS10 gene and regulates the expression of RPS10 protein by inhibiting the initiation 
of RPS10 translation [37]. Singh et al. claimed that the activity of ribonuclease E could be regulated by the interaction of RPL4 and ribonuclease E, which leads to changes in mRNA composition during stress [38].

Researchers have found a strong link between $M$. genitalium infection and cancer. Miyake et al. and Erturhan et al. found that M. genitalium infection was associated with prostate cancer $[39,40]$. Idahl et al. found that $M$. genitalium infection was correlated with epithelial ovarian tumors [41]. M. genitalium is associated with tumorigenesis, but this correlation is not directly related to HIV infection, indicating that the cause of tumors induced by M. genitalium is also unclear. Our findings may provide some evidence, because we found abnormal cell proliferation after M. genitalium infection. Our results demonstrated that RPL35 was potentially the interacting protein of $\mathrm{rMgPa}$, and the ensuing interaction could promote the proliferation of SV-HUC-1 cells. Therefore, we speculate that RPL35 acts as a transcription inhibitor at the early stage of $M$. genitalium's invasion of host cells. This inhibition can be relieved when rMgPa binds to RPL35. The increase in protein translation levels can stimulate cell proliferation and provide nutrition for the growth and development of M. genitalium at the early stage of infection, which might be an important mechanism for M. genitalium to survive and colonize host cells during early infection. When M. genitalium's colonization time in host cells is prolonged, the balance between rRNA and RP is broken, and the homeostasis of the intracellular environment is destroyed. Hence, the transcription and translation of proteins in epithelial cells are blocked, which leads to cell death, thus, exerting the bacterium's pathogenicity on host epithelial cells. In future, we intend to study the effect of rMgPa and RPL35 interaction on cell function, and further assess the possible mechanism of the interaction between M. genitalium and RP to provide an experimental basis for understanding the survival strategies of $M$. genitalium and the biological function of rMgPa.

In conclusion, the results of this study demonstrated that RPL35 is the interacting protein of $\mathrm{MgPa}$, and the interaction between $\mathrm{MgPa}$ and RPL35 can enhance the expression of transcription-initiation and translation-related proteins, and thus promote cell proliferation, which lays an experimental foundation for understanding the interaction between M. genitalium and host cells and the possible survival mechanisms of M. genitalium.

\section{Materials and Methods}

\subsection{Chemicals and Reagents}

The purification of recombinant $M$. genitalium protein of adhesion ( $\mathrm{rMgPa}, 1075-1444 \mathrm{aa})$ using Ni-nitrilotriacetic acid (NTA) beads and the purification of the corresponding antirMgPa polyclonal antibody via affinity chromatography using $\mathrm{CNBr}$-activated Sepharose $4 \mathrm{~B}$ were performed as described in our previous study [42].

\subsection{Preparation of the T7 Phage-Displayed cDNA Library of SV-HUC-1 Cells}

The SV40 immortalized human urothelium cells (SV-HUC-1) (ATCC, CRL-9520) containing the SV40 genome were purchased from the Chinese Academy of Sciences Cell Bank (Shanghai, China). The preparation of the T7 phage-displayed cDNA library of SV-HUC-1 cells was performed as described by Luo et al. [43]. Approximately $150 \mu \mathrm{g}$ of the total RNA of SV-HUC-1 cells was isolated using the nucleic acid isolation kit (Invitrogen, AM1975, Carlsbad, CA, USA). Highly purified mRNA was isolated by three rounds of purification using Magnetight Oligo (dT) particles by following instructions provided by the manufacturer (Promega, Madison, WI, USA). The T7 phage-displayed cDNA library of SV-HUC-1 cells was constructed using the T7 Select 10-3b cloning system (Novagen, Madison, WI, USA) as described by manufacturer. Briefly, the synthetic steps of reverse transcription (RT) from RNA to cDNA refer to the description of the reversed transcriptase box (Beyotime Biotech, Shanghai, China). The cDNA fragments were then connected with a T7 $10-3 \mathrm{~b}$ carrier arm at $16{ }^{\circ} \mathrm{C}$ overnight, after which a $5 \mu \mathrm{L}$ ligation product was added to a $25 \mu \mathrm{L} \mathrm{T7}$ select packaging extract protein for packaging in vitro. Finally, the packaging reaction was terminated by adding LB medium overnight at $37^{\circ} \mathrm{C}$. The phage 
clones were selected randomly for the amplification of the exogenous DNA sequence by PCR using 5'-GGAGCTGTCGTATTCCAGTC- $3^{\prime}$ and $5^{\prime}$-AACCCCTCAAGACCCGTTTA- $3^{\prime}$ as the forward and reverse primers, respectively, to assess the diversity of the library. The detection of titers for the SV-HUC-1 T7 phage-displayed cDNA library was shown in .

\subsection{Biopanning and Analysis}

The biopanning of T7 phage-displayed cDNA library of SV-HUC-1 cells was performed as described by Wang et al. [44]. Briefly, a microplate was coated using $100 \mu \mathrm{g} / \mathrm{mL}$ $\mathrm{rMgPa}$. The microplate was kept overnight at $4{ }^{\circ} \mathrm{C}$, and then the nonspecific sites were blocked the next day with $5 \%$ blocking reagent (skimmed milk) for $2 \mathrm{~h}$ at $4{ }^{\circ} \mathrm{C}$. Subsequently, $200 \mu \mathrm{L}$ of T7 phage-displayed cDNA library $\left(3.2 \times 10^{8} \mathrm{pfu}\right)$ was added into the wells of the microplate and incubated for $60 \mathrm{~min}$ at $37^{\circ} \mathrm{C}$. The wells were then washed six times with Tris- $\mathrm{HCl}$ containing $0.1 \%$ Tween- 20 (TBST) to remove the unbound phages. The bound phages were eluted with $200 \mu \mathrm{L}$ of a T7 high salt elution buffer $(1 \mathrm{M} \mathrm{NaCl}, 20 \mathrm{mM}$ Tris- $\mathrm{HCl}, 2 \mathrm{mM} \mathrm{KCl}, 1 \mathrm{mM}$ EDTA) and then were amplified in Escherichia coli BLT5403. The amplified phages were then subjected to three consecutive rounds of biopanning as described above, to enrich $\mathrm{rMgPa}$-specific phages.

Phage titers were measured using plaque assay as described in the Novagen T7 Select ${ }^{\mathrm{TM}}$ manual. Thirty-two plaques were randomly selected, and PCR was performed at $94{ }^{\circ} \mathrm{C}$ for $10 \mathrm{~min}, 50{ }^{\circ} \mathrm{C}$ for $1 \mathrm{~min}, 72{ }^{\circ} \mathrm{C}$ for $1 \mathrm{~min}$, for 30 cycles and finally extended at $72{ }^{\circ} \mathrm{C}$ for 10 min using T7 primers as described above.

\subsection{Phage ELISA and Dot Immunobinding Assay}

Representative phages were amplified with E. coli BLT5403 for further ELISA analysis. Ninety-six-well plates were coated with $100 \mu \mathrm{L}$ of rMgPa. Next, $150 \mu \mathrm{L}$ of amplified phages (approximately $3 \times 10^{8} \mathrm{pfu}$ ) were added to each well, and incubated at $37^{\circ} \mathrm{C}$ for $2 \mathrm{~h}$, washed with TBS six times, subjected to $100 \mu \mathrm{L}$ (per well) of diluted T7 tail fiber monoclonal antibody (Cat. bs-2107R, Bosen Co., Ltd, Guangdong, China), and incubated for $1 \mathrm{~h}$ at room temperature. The unbound T7 tail fiber monoclonal antibody was removed with TBST after the incubation process. Then, $100 \mu \mathrm{L}$ of diluted HRP-conjugated goat anti-rabbit IgG antibody (ab6721, Abcam, Cambridge, UK) was introduced into each well, and the mixture was left to incubate for $1 \mathrm{~h}$ at room temperature. The plates were washed with TBST at the end of the incubation period. In the final step, the contents of the microplate were colored for observation at $37^{\circ} \mathrm{C}$ for $15 \mathrm{~min}$ using a tetramethylbenzidine (TMB) solution as a substrate. After adding $\mathrm{H}_{2} \mathrm{SO}_{4}(2 \mathrm{M})$, the optical density (OD) value for each well was obtained at $450 \mathrm{~nm}$ using a multifunctional microplate reader, Infinite ${ }^{\circledR}$ F50 (Mannedorf, Switzerland).

A dot immunobinding assay for phages was performed as described by Ali [45]. Briefly, each representative phage (approximately $3 \times 10^{8} \mathrm{pfu}$ ) was tested on each grid of a poly vinylidene fluoride (PVDF) membrane, followed by drying of the PVDF membrane at room temperature and blocking with skim milk $(0.5 \%)$ at $4{ }^{\circ} \mathrm{C}$ overnight. The PVDF membrane was incubated with $100 \mu \mathrm{g} / \mathrm{mL}$ of the rMgPa protein in a warm box for $2 \mathrm{~h}$ and then washed six times. Following the $2 \mathrm{~h}$ incubation, a primary antibody (rabbit anti-rMgPa antibody) was added, and the reaction was left for another $2 \mathrm{~h}$ incubation at $37^{\circ} \mathrm{C}$. The membrane was then washed five times, and a third incubation was performed, this time with a secondary antibody (HRP-labeled goat anti-Rabbit IgG antibody) for $1 \mathrm{~h}$ at $37^{\circ} \mathrm{C}$. Finally, the membrane was washed five times, colored with TMB (Beyotime, Shanghai, China) for observation, and then developed and fixed.

\subsection{Interaction Assays between $r M g P a$ and RPL35 Using Far-Western Blotting}

The extraction of total protein from SV-HUC-1 cells was performed as described by

Deng et al. [16]. Briefly, when the SV-HUC-1 cells were about $90 \%$ confluent, cells were digested using trypsin and centrifuged at $1000 \mathrm{rpm}$ for $6 \mathrm{~min}$ at room temperature. Then, $100 \mu \mathrm{L}$ of RIPA (50 mM Tris-HCl, pH7.4, $150 \mathrm{mM} \mathrm{NaCl}, 1 \% \mathrm{NP}-40$ ) and $100 \mu \mathrm{g} / \mathrm{mL}$ of PMSF 
was added, and the reaction mixture was allowed to incubate in the icebox for $30 \mathrm{~min}$. The resulting content was subjected to centrifugation at $12,000 \mathrm{rpm}$ for $15 \mathrm{~min}$ at $4{ }^{\circ} \mathrm{C}$. The supernatant, namely the protein of interest, was collected and stored at $-20{ }^{\circ} \mathrm{C}$.

The interaction between rMgPa and RPL35 was identified from total cell proteins using far-Western blotting as described by Fecková et al. [46]. Briefly, $10 \mu \mathrm{g}$ of rMgPa was separated by $12 \%$ of SDS-PAGE and transferred to a PVDF membrane using a semi-dry transfer unit. After blocking with $5 \%$ skim milk overnight at $4{ }^{\circ} \mathrm{C}$, the PVDF membrane was incubated with total cell proteins (1:500) for $6 \mathrm{~h}$ at $4{ }^{\circ} \mathrm{C}$. A second incubation of the PVDF membrane followed with a rabbit anti-RPL35 antibody (1:200) (Cat. GR303483-1, Abcam, Cambridge, UK) for $2 \mathrm{~h}$ at $37^{\circ} \mathrm{C}$. The membrane was then washed six times with TBST, incubated with an HRP-conjugated goat anti-rabbit IgG antibody (1:4000) for $2 \mathrm{~h}$ at $37^{\circ} \mathrm{C}$, and washed six times with TBST. A chemiluminescent imaging system (Syngene, Frederick, MD, USA) was used to detect immunoreactive bands on the membrane.

\subsection{Co-localization Analysis of $r M g P a$ and RPL35 in the SV-HUC-1 Cells}

Co-localization analysis of $\mathrm{rMgPa}$ and RPL35 was performed as described by Deng et al. The MgPa target gene was amplified using $5^{\prime}$-ggaattcatgcctaaatcactgtgggatc- $3^{\prime}$ and $5^{\prime}$-ccgctcgagcactactataggaacagtt- $3^{\prime}$ as up and down primers, respectively. The conditions for amplification were predenaturation at $94{ }^{\circ} \mathrm{C}$ for $5 \mathrm{~min}$, denaturation at $94{ }^{\circ} \mathrm{C}$ for $30 \mathrm{~s}$, annealing at $52{ }^{\circ} \mathrm{C}$ for $45 \mathrm{~s}$, extension at $72{ }^{\circ} \mathrm{C}$ for $1 \mathrm{~min} 20 \mathrm{~s}$ for 35 cycles, and extension for $7 \mathrm{~min}$ at $72^{\circ} \mathrm{C}$. PCR products were then digested with EcoR I and Xho I (Thermo Science, Waltham, MA, USA) before being cloned into the corresponding restriction sites of the pcDNA3.1(+) vector to construct the recombinant vector pcDNA3.1(+)/MgPa (Supplementary Materials Figure S3). The expression of the rMgPa proteins as detected by Western blotting is shown in Supplementary Materials Figure S4. The pcDNA3.1(+)/MgPa vector was transfected into SV-HUC-1 cells. The transfected cells were prepared and incubated with a primary antibody mixture containing a rabbit anti-rMgPa antibody (1:1000) and a mouse anti-RPL35 antibody (Cat. H00011224-A01, Invitrogen, AM1975, Carlsbad, CA, USA), washed six times with TBST, and then incubated with a secondary antibody mixture containing a FITC-conjugated AffiniPure goat anti-mouse IgG $(H+G)$ (1:200) (Cat. CW0152S, Beyotime, Shanghai, China) and a TRITC-conjugated AffiniPure goat anti-rabbit IgG $(\mathrm{H}+\mathrm{L})(1: 200)$ (Cat. CW0114S, Beyotime, Shanghai, China) for $2 \mathrm{~h}$ at $37^{\circ} \mathrm{C}$. After washing the samples six times, $200 \mu \mathrm{L}$ of DAPI was added for the staining of nuclei. Staining with DAPI caused the delineation of nuclei of SV-HUC-1 cells, helping identify their intracellular planes. The exposure time was concordant for all images in each set of the experiment, and the images were viewed under an inverted TE2000-S microscope (Nikon, Tokyo, Japan).

\subsection{Analysis of the Transcriptome of SV-HUC-1 Cells by TMT Analysis}

The total cellular protein was extracted from the pcDNA3.1(+)/MgPa-transfected and the empty-plasmid-transfected SV-HUC-1 cells, respectively, using $300 \mu \mathrm{L}$ of a RIPA (0.1\% PMSF) lysate. TMT analysis was carried out by the Abace Biotechnology Company (Beijing, China). Differential proteins were sorted out and classified, with 0.05 considered the significant threshold. Selecting Homo sapiens as the background and species, the gene ontology (GO) information of altered protein expression was analyzed for biological processing (BP) and cell composition (CC).

\subsection{RT-qPCR Analyses of the mRNA Expression of Differential Protein}

Total cellular RNA was isolated from SV-HUC-1 cells using $500 \mu \mathrm{L}$ of Trizol reagent (Beyotime Biotech, Shanghai, China) according to the manufacturer's recommendations. Based on the results of the TMT analyses, real-time quantitative reverse transcription PCR (RT-qPCR) was used to detect the RNA level of proteins associated with cell transcription and translation functions. The primer sequences of these proteins were shown in Table 3. The synthetic steps for reverse transcription from RNA to cDNA were performed using 
the FastQuant cDNA first-strand synthesis kit (Beyotime, Shanghai, China). Total RNA $(1 \mu \mathrm{g})$ was incubated for $60 \mathrm{~min}$ at $42{ }^{\circ} \mathrm{C}$ and $10 \mathrm{~min}$ at $80^{\circ} \mathrm{C}$. The cDNA samples from RT reactions were amplified using the $2 \times$ Super Real PreMixplus MasterMix (Tiangen Biotech Co., Ltd., Beijing, China). The thermal cycling conditions were as follows: $95^{\circ} \mathrm{C}$ for $5 \mathrm{~min}$, followed by 40 cycles at $95^{\circ} \mathrm{C}$ for $15 \mathrm{~s}, 58^{\circ} \mathrm{C}$ for $20 \mathrm{~s}$, and $72{ }^{\circ} \mathrm{C}$ for $15 \mathrm{~s}$ using Roche LightCycler ${ }^{\circledR} 96$.

Table 3. Primer sequences of the target genes.

\begin{tabular}{|c|c|}
\hline Gene & Primer Sequence $\left(5^{\prime}-3^{\prime}\right)$ \\
\hline GAPDH & $\begin{array}{l}\text { F: 5'-GCACCGTCAAGGCTGAGAAC-3' } \\
\text { R:5'-TGGGAAGACGCCAGTGGA-3' }\end{array}$ \\
\hline EIF2 & $\begin{array}{l}\text { F:5'-CGAGAAGCACAGCAAGAACATCAC-3' } \\
\text { R:5'-TCCTACAGACGCCTTCTCTTCGG-3' }\end{array}$ \\
\hline SRP68 & $\begin{array}{l}\mathrm{F}: 5^{\prime}-\mathrm{CTCTCGCACCTGGTCTCCTACG-3'} \\
\mathrm{R}: 5^{\prime} \text {-GCTCCAACACGCTGCCACTG-3' }\end{array}$ \\
\hline SERBP1 & $\begin{array}{l}\text { F:5'-AAGAGGCTCATGCTGAAGATTCGG-3' } \\
\text { R:5'-AGGAGCAGAAGCACTTGACTTGTC-3' }\end{array}$ \\
\hline RPL35A & $\begin{array}{l}\text { F:5'-TGGAAGGCTGTGGTCCAAGGC-3' } \\
\text { R:5'-CGCCAGGAGTGACTGTGTTGTTC-3' }\end{array}$ \\
\hline$E G F$ & $\begin{array}{l}\text { F:5'-ATGGCCAATCTGGATGGTTC-3' } \\
\text { R:5'-CATGCTGCCTTGGAGACGTA-3' }\end{array}$ \\
\hline$T G F-\beta$ & $\begin{array}{l}\text { F:5'-GTGAAACACCGAGGACACCT-3' } \\
\text { R:5'-GGTGCGTTGATAAATGTGG-3' }\end{array}$ \\
\hline
\end{tabular}

\subsection{The Detection of Cell Proliferation Using the MTT Assay}

MTT assays were used to evaluate the survival of cells in different groups. The EG included the pcDNA3.1 (+)/MgPa-transfected cells, the CG the empty plasmid pcDNA3.1 (+) cells, and the ZG the medium treatment group, and the ZG contained PBS. Ten microliters of MTT (Beyotime, China) was added into a 96-well plate. After an additional incubation at $37^{\circ} \mathrm{C}$ and $5 \% \mathrm{CO}_{2}$ for $4 \mathrm{~h}, 100 \mu \mathrm{L}$ of dimethyl sulfoxide was added into each well. After an additional incubation at $37^{\circ} \mathrm{C}, 5 \% \mathrm{CO}_{2}$ for $4 \mathrm{~h}, 100 \mu \mathrm{L}$ dimethyl sulfoxide was added into each well. Finally, the absorbance was measured at $495 \mathrm{~nm}$ using a multifunctional Microplate Infinite ${ }^{\circledR}$ F50 reader.

\subsection{Statistical Analysis}

All statistical analysis were conducted using the GraphPad Instant statistical package (GraphPad Software Inc., San Diego, CA, USA), and data were analyzed using the SPSS18.0 statistical software. The data are expressed as mean \pm standard deviation. The criterion for statistical significance was set at $p<0.05$ and $p<0.01$.

Supplementary Materials: The following are available online at https:/ /www.mdpi.com/article/ 10.3390/pathogens10111449/s1, Figure S1: The detection of titer for SV-HUC-1 T7 phage display cDNA library, Figure S2: Agarose gel electrophoresis analysis of PCR products of the displayed phages, Figure S3: Construction of pcDNA3.1(+)/rMgPa. Mycoplasmal TGA codons were substituted with TGG (3223 4092aa), Figure S4: Expression of the rMgPa proteins as detected by western blotting, Figure S5: Blast mapping of BC071915.1, BC094828.1 and BC000348.2 of RPL35 subunits with exogenous sequences.

Author Contributions: Conceptualization, Y.Z.; methodology, Y.Z.; validation, P.D.; formal analysis, P.D., X.D., L.L., D.L., Y.L. and P.L.; data curation, P.D., X.D., L.L., D.L., Y.L. and P.L.; writing—original draft preparation, P.D.; writing—review and editing, P.D.; supervision, Y.Z. All authors have read and agreed to the published version of the manuscript.

Funding: This work was supported by the National Natural Science Foundation of China (no: 31370207, 81871256). 
Institutional Review Board Statement: This article does not contain any studies with human participants or animals.

Informed Consent Statement: Not applicable.

Data Availability Statement: Data are available on reasonable request to the corresponding author.

Conflicts of Interest: The authors declare no conflict of interest.

\section{References}

1. Rowlinson, E.; Hughes, J.P.; Chambers, L.C.; Lowens, M.S.; Morgan, J.L.; Robinson, T.S.; Romano, S.S.; Leipertz, G.L.; Soge, O.O.; Golden, M.R.; et al. Incidence of Nongonococcal Urethritis in Men Who Have Sex with Women and Associated Risk Factors. Sex Transm. Dis. 2021, 48, 341-346. [CrossRef]

2. Zhao, N.; Li, K.T.; Gao, Y.Y.; Xu, J.J.; Huang, D.S. Mycoplasma genitalium and Mycoplasma hominis are prevalent and correlated with HIV risk in MSM: A cross-sectional study in Shenyang, China. BMC Infect. Dis. 2019, 19, 494. [CrossRef]

3. Liu, Y.; Dong, Y.; Wen, Y.; Peng, S.; Liao, J.; Liu, Y. Association of Mycoplasma fermentans and the risk of HIV-1 infection: A meta-analysis. Medicine 2020, 99, e18499. [CrossRef]

4. Smullin, C.P.; Green, H.; Peters, R.; Nyemba, D.; Qayiya, Y.; Myer, L.; Klausner, J.; Joseph Davey, D. Prevalence and incidence of Mycoplasma genitalium in a cohort of HIV-infected and HIV-uninfected pregnant women in Cape Town, South Africa. Sex Transm. Infect. 2020, 96, 501-508. [CrossRef]

5. Kim, S.J.; Paik, D.J.; Lee, J.S.; Lee, H.S.; Seo, J.T.; Jeong, M.S.; Lee, J.H.; Park, D.W.; Han, S.; Lee, Y.K.; et al. Effects of infections with five sexually transmitted pathogens on sperm quality. Clin. Exp. Reprod. Med. 2017, 44, 207-213. [CrossRef]

6. Reddy, S.P.; Rasmussen, W.G.; Baseman, J.B. Isolation and characterization of transposon Tn4001-generated, cytadherencedeficient transformants of Mycoplasma pneumoniae and Mycoplasma genitalium. FEMS Immunol. Med. Microbiol. 1996, 15, 199-211. [CrossRef] [PubMed]

7. Krause, D.C.; Leith, D.K.; Wilson, R.M.; Baseman, J.B. Identification of Mycoplasma pneumoniae proteins associated with hemadsorption and virulence. Infect. Immun. 1982, 35, 809-817. [CrossRef] [PubMed]

8. Aparicio, D.; Scheffer, M.P.; Marcos-Silva, M.; Vizarraga, D.; Sprankel, L.; Ratera, M.; Weber, M.S.; Seybert, A.; Torres-Puig, S.; Gonzalez-Gonzalez, L.; et al. Structure and mechanism of the Nap adhesion complex from the human pathogen Mycoplasma genitalium. Nat. Commun. 2020, 11, 2877. [CrossRef] [PubMed]

9. García-Morales, L.; González-González, L.; Querol, E.; Piñol, J. A minimized motile machinery for Mycoplasma genitalium. Mol. Microbiol. 2016, 100, 125-138. [CrossRef] [PubMed]

10. Aparicio, D.; Torres-Puig, S.; Ratera, M.; Querol, E.; Piñol, J.; Pich, O.Q.; Fita, I. Mycoplasma genitalium adhesin P110 binds sialic-acid human receptors. Nat. Commun. 2018, 9, 4471. [CrossRef]

11. McGowin, C.L.; Popov, V.L.; Pylesm, R.B. Intracellular Mycoplasma genitalium infection of human vaginal and cervical epithelial cells elicits distinct patterns of inflammatory cytokine secretion and provides a possible survival niche against macrophagemediated killing. BMC Microbiol. 2009, 9, 139. [CrossRef] [PubMed]

12. Sloan, K.E.; Warda, A.S.; Sharma, S.; Entian, K.D.; Lafontaine, D.; Bohnsack, M.T. Tuning the ribosome: The influence of rRNA modification on eukaryotic ribosome biogenesis and function. RNA Biol. 2017, 14, 1138-1152. [CrossRef] [PubMed]

13. Kimura, S.; Sakai, Y.; Ishiguro, K.; Suzuki, T. Biogenesis and iron-dependency of ribosomal RNA hydroxylation. Nucleic Acids Res. 2017, 45, 12974-12986. [CrossRef]

14. Dong, Z.; Abbas, M.N.; Kausar, S.; Yang, J.; Li, L.; Tan, L.; Cui, H. Biological Functions and Molecular Mechanisms of Antibiotic Tigecycline in the Treatment of Cancers. Int. J. Mol. Sci. 2019, 20, 3577. [CrossRef]

15. Mikhaylina, A.O.; Kostareva, O.S.; Sarskikh, A.V.; Fedorov, R.V.; Piendl, W.; Garber, M.B.; Tishchenko, S.V. Investigation of the regulatory function of archaeal ribosomal protein L4. Biochemistry 2014, 79, 69-76. [CrossRef]

16. Deng, X.; Dai, P.; Yu, M.; Chen, L.; Zhu, C.; You, X.; Li, L.; Zeng, Y. Cyclophilin A is the potential receptor of the Mycoplasma genitalium adhesion protein. Int. J. Med. Microbiol. 2018, 308, 405-412. [CrossRef]

17. Huang, C.; Zhu, H.L.; Xu, K.R.; Wang, S.Y.; Fan, L.Q.; Zhu, W.B. Mycoplasma and ureaplasma infection and male infertility: A systematic review and meta-analysis. Andrology 2015, 3, 809-816. [CrossRef]

18. Ueno, P.M.; Timenetsky, J.; Centonze, V.E.; Wewer, J.J.; Cagle, M.; Stein, M.A.; Krishnan, M.; Baseman, J.B. Interaction of Mycoplasma genitalium with host cells: Evidence for nuclear localization. Microbiology 2008, 154, 3033-3041. [CrossRef]

19. McGowin, C.L.; Radtke, A.L.; Abraham, K.; Martin, D.H.; Herbst-Kralovetz, M. Mycoplasma genitalium infection activates cellular host defense and inflammation pathways in a 3-dimensional human endocervical epithelial cell model. J. Infect. Dis. 2013, 207, 1857-1868. [CrossRef] [PubMed]

20. Baseman, J.B.; Lange, M.; Criscimagna, N.L.; Giron, J.A.; Thomas, C.A. Interplay between mycoplasmas and host target cells. Microb. Pathog. 1995, 19, 105-116. [CrossRef] [PubMed]

21. Dallo, S.F.; Baseman, J.B. Intracellular DNA replication and long-term survival of pathogenic mycoplasmas. Microb. Pathog. 2000, 29, 301-309. [CrossRef]

22. Addepalli, B.; Rao, S.; Hunt, A.G. Phage display library screening for identification of interacting protein partners. Methods Mol. Biol. 2015, 1255, 147-158. 
23. Piggott, A.M.; Karuso, P. Identifying the cellular targets of natural products using T7 phage display. Nat. Prod. Rep. 2016, 33, 626-636. [CrossRef] [PubMed]

24. Sakamoto, K.; Kamada, Y.; Sameshima, T.; Yaguchi, M.; Niida, A.; Sasaki, S.; Miwa, M.; Ohkubo, S.; Sakamoto, J.I.; Kamaura, M.; et al. K-Ras(G12D)-selective inhibitory peptides generated by random peptide T7 phage display technology. Biochem. Biophys. Res. Commun. 2017, 484, 605-611. [CrossRef]

25. Talwar, H.; Hanoudi, S.N.; Draghici, S.; Samavati, L. Novel T7 Phage Display Library Detects Classifiers for Active Mycobacterium Tuberculosis Infection. Viruses 2018, 10, 375. [CrossRef] [PubMed]

26. Liao, Y.; Luo, D.; Peng, K.; Zeng, Y. Cyclophilin A: A key player for etiological agent infection. Appl. Microbiol. Biotechnol. 2021, 105, 1365-1377. [CrossRef]

27. Li, L.; Luo, D.; Liao, Y.; Peng, K.; Zeng, Y. Mycoplasma genitalium Protein of Adhesion Induces Inflammatory Cytokines via Cyclophilin A-CD147 Activating the ERK-NF-kB Pathway in Human Urothelial Cells. Front. Immunol. 2020, 11, 2052. [CrossRef]

28. Plow, E.F.; Doeuvre, L.; Das, R. So many plasminogen receptors: Why. J. Biomed. Biotechnol. 2012, 2012, 141806. [CrossRef]

29. Huang, A.; Zhang, M.; Li, T.; Qin, X. Serum Proteomic Analysis by Tandem Mass Tags (TMT) Based Quantitative Proteomics in Gastric Cancer Patients. Clin. Lab. 2018, 64, 855-866. [CrossRef] [PubMed]

30. Sandberg, A.; Branca, R.M.; Lehtiö, J.; Forshed, J. Quantitative accuracy in mass spectrometry based proteomics of complex samples: The impact of labeling and precursor interference. J. Proteomics. 2014, 96, 133-144. [CrossRef] [PubMed]

31. Crozier, T.; Tinti, M.; Wheeler, R.J.; Ly, T.; Ferguson, M.; Lamond, A.I. Proteomic Analysis of the Cell Cycle of Procylic Form Trypanosoma brucei. Mol. Cell Proteom. 2018, 17, 1184-1195. [CrossRef]

32. Kisly, I.; Remme, J.; Tamm, T. Ribosomal protein eL24, involved in two intersubunit bridges, stimulates translation initiation and elongation. Nucleic Acids Res. 2019, 47, 406-420. [CrossRef] [PubMed]

33. O'Leary, M.N.; Schreiber, K.H.; Zhang, Y.; Duc, A.C.; Rao, S.; Hale, J.S.; Academia, E.C.; Shah, S.R.; Morton, J.F.; Holstein, C.A.; et al. The ribosomal protein Rpl22 controls ribosome composition by directly repressing expression of its own paralog, Rpl22l1. PLoS Genet. 2013, 9, e1003708. [CrossRef]

34. Oršolić, I.; Bursać, S.; Jurada, D.; Drmić Hofman, I.; Dembić, Z.; Bartek, J.; Mihalek, I.; Volarević, S. Cancer-associated mutations in the ribosomal protein L5 gene dysregulate the HDM2/p53-mediated ribosome biogenesis checkpoint. Oncogene 2020, 39, 3443-3457. [CrossRef]

35. Warner, J.R.; McIntosh, K.B. How common are extraribosomal functions of ribosomal proteins. Mol. Cell 2009, 34, 3-11. [CrossRef] [PubMed]

36. Da Costa, L.; Narla, A.; Mohandas, N. An update on the pathogenesis and diagnosis of Diamond-Blackfan anemia. F1000Research 2018, 7. [CrossRef]

37. Miyata, S.; Furuki, K.; Oshima, K.; Sawayanagi, T.; Nishigawa, H.; Kakizawa, S.; Jung, H.Y.; Ugaki, M.; Namba, S. Complete nucleotide sequence of the S10-spc operon of phytoplasma: Gene organization and genetic code resemble those of Bacillus subtilis. DNA Cell Biol. 2002, 21, 527-534. [CrossRef] [PubMed]

38. Singh, D.; Chang, S.J.; Lin, P.H.; Averina, O.V.; Kaberdin, V.R.; Lin-Chao, S. Regulation of ribonuclease E activity by the L4 ribosomal protein of Escherichia coli. Proc. Natl. Acad. Sci. USA 2009, 106, 864-869. [CrossRef]

39. Miyake, M.; Ohnishi, K.; Hori, S.; Nakano, A.; Nakano, R.; Yano, H.; Ohnishi, S.; Owari, T.; Morizawa, Y.; Itami, Y.; et al. Mycoplasma genitalium Infection and Chronic Inflammation in Human Prostate Cancer: Detection Using Prostatectomy and Needle Biopsy Specimens. Cells 2019, 8, 212. [CrossRef] [PubMed]

40. Erturhan, S.M.; Bayrak, O.; Pehlivan, S.; Ozgul, H.; Seckiner, I.; Sever, T.; Karakök, M. Can mycoplasma contribute to formation of prostate cancer? Int. Urol. Nephrol. 2013, 45, 33-38. [CrossRef] [PubMed]

41. Idahl, A.; Lundin, E.; Jurstrand, M.; Kumlin, U.; Elgh, F.; Ohlson, N.; Ottander, U. Chlamydia trachomatis and Mycoplasma genitalium plasma antibodies in relation to epithelial ovarian tumors. Infect. Dis. Obstet. Gynecol. 2011, 2011, 824627. [CrossRef] [PubMed]

42. Zeng, Y.; Liu, L.; He, J.; Liu, Y.; Zhu, C.; You, X.; Wu, Y. Screening and identification of the mimic epitope of the adhesion protein of Mycoplasma genitalium. Can. J. Microbiol. 2012, 58, 898-908. [CrossRef]

43. Luo, D.; Wang, L.; Liu, H.; Li, L.; Liao, Y.; Yi, X.; Yan, X.; Wan, K.; Zeng, Y. Ribokinase screened from T7 phage displayed Mycobacterium tuberculosis genomic DNA library had good potential for the serodiagnosis of tuberculosis. Appl. Microbiol. Biotechnol. 2019, 103, 5259-5267. [CrossRef] [PubMed]

44. Wang, L.; Deng, X.; Liu, H.; Zhao, L.; You, X.; Dai, P.; Wan, K.; Zeng, Y. The mimic epitopes of Mycobacterium tuberculosis screened by phage display peptide library have serodiagnostic potential for tuberculosis. Pathog. Dis. 2016, 74, ftw091. [CrossRef]

45. Ali, A. Rapid detection of fifteen known soybean viruses by dot-immunobinding assay. J. Virol. Methods 2017, 249, 126-129. [CrossRef] [PubMed]

46. Fecková, B.; Kimáková, P.; Ilkovičová, L.; Szentpéteriová, E.; Debeljak, N.; Solárová, Z.; Sačková, V.; Šemeláková, M.; Bhide, M.; Solár, P. Far-western blotting as a solution to the non-specificity of the anti-erythropoietin receptor antibody. Oncol. Lett. 2016, 12, 1575-1580. [CrossRef] 